Gascoigne, J. A. \& Gascoigne, M. M. (1960). J. gen. Microbiol. 22, 242-248

\title{
The Xylanases of Fusarium roseum
}

\author{
By J. A. GASCOIGNE AND MARGARET M. GASCOIGNE
}

The British Rayon Research Association, Wythenshawe, Manchester 22

SUMMARY: The xylanase activities of 13 fungi have been investigated. Fusarium roseum produced an extracellular xylanase system, which has been fractionated by ethanol precipitation. One of the fractions had no action on cellulose and the carbohydrate-hydrolysing enzymes of this fraction have been studied; xylanase and transpentosylase activities were present. The xylanase had optimum activity at pH 6.3, was progressively deactivated above $30^{\circ}$; it catalysed the random scission of xylan chains. The inducible nature of cellulases is discussed.

Enzymes which catalyse the hydrolysis of hemicelluloses have been found in molluscs, insects, plants and micro-organisms. Substrates for these enzymes have included xylans, mannans, arabans, mannogalactans and wood fractions. The hemicellulases of fungi occur both intra- and extracellularly, although it has been shown (Bose \& Sarkar, 1937) that some fungi liberate more hemicellulase into the surrounding medium than is present within the cells. In an investigation of the degradation of cellulosic materials it was found that both xylanases and cellulases could be found in the culture medium of Fusarium roseum growing on xylan containing medium.

\section{METHODS}

Xylan was prepared from esparto grass (Stipa tenacissima L.) by the method of Chanda, Hirst, Jones \& Percival (1950), but omitting purification via the copper complex. Acid hydrolysis of this xylan gave xylose, arabinose and a trace of glucose.

Mineral salts medium (g./l.): $\mathrm{KCl}, 0.5 ; \mathrm{MgSO}_{4} .7 \mathrm{H}_{2} \mathrm{O}, 0.5 ;\left(\mathrm{NH}_{4}\right)_{2} \mathrm{HPO}_{4}, 2.5$; $\mathrm{NaH}_{2} \mathrm{PO}_{4}, 0.5 ; \mathrm{CaCl}_{2} \mathrm{H}_{2} \mathrm{O}, 0.01 ; \mathrm{FeSO}_{4} .7 \mathrm{H}_{2} \mathrm{O}, 0.01 ; \mathrm{ZnSO}_{4} .7 \mathrm{H}_{2} \mathrm{O}, 0.002 ;$ adjusted to $\mathrm{pH} 6 \cdot \mathbf{0}$.

Paper chromatography. The descending technique was used with the solvent $n$-butanol + ethanol $(95 \%)+$ water $(52+32+16$ by volume) on Whatman no. 1 paper. Reducing sugars were detected by the alkaline silver nitrate reagent of Trevelyan, Proctor \& Harrison (1950).

Fungi. The fungi used were obtained from the sources listed in Table 1.

Action of fungi on xylan. Some fungi were tested for xylanase production by growth at $30^{\circ}$ on the mineral salts medium containing xylan $(1 \%, \mathrm{w} / \mathrm{v})$; examination of the cultures after $96 \mathrm{hr}$. by paper chromatography revealed the reducing sugars recorded in Table 1 (amounts assessed by visual comparisons only). From these observations and the speed of fungal growth it was decided to investigate the extracellular xylanases produced by Fusarium roseum. 
Growth of Fusarium roseum. The fungus grew well in static, shaken and aerated cultures on the mineral salts + xylan medium. Starter cultures were prepared by static growth for 21 days at $30^{\circ}$ on this medium, which had been inoculated from a slope culture of the fungus on potato glucose agar. Ten conical flasks ( 1 l. capacity), each containing $450 \mathrm{ml}$. of the medium, were sterilized $\left(115^{\circ} / 15 \mathrm{~min}\right.$.) and inoculated from the starter cultures. The flasks were shaken on a rotary action shaker at $c .200$ oscillations/min. for 13 days at $28^{\circ}-30^{\circ}$; the $\mathrm{pH}$ value was then 6.7 and a rose-coloured pigment had developed.

Table 1. Catabolic products from xylan

\begin{tabular}{|c|c|c|c|}
\hline \multirow[b]{2}{*}{ Fungus } & \multirow{2}{*}{ Source } & \multicolumn{2}{|c|}{ Reducing sugars produced } \\
\hline & & Xylose + arabinose & Oligosaccharides \\
\hline $\begin{array}{l}\text { Penicillium luteum } \\
\text { Zukal }\end{array}$ & $\begin{array}{l}\text { London School of Hygiene } \\
\text { and Tropical Medicine }\end{array}$ & None & None \\
\hline P. pinophilum & C.M.I. 22813 & + & + \\
\hline P. funiculosum & C.M.I. 40235 & + & + \\
\hline $\begin{array}{l}P \text {. viridicatum } \\
\text { Westling }\end{array}$ & $\begin{array}{l}\text { Chemistry Department, } \\
\text { University of Birmingham }\end{array}$ & ++ & + \\
\hline $\begin{array}{l}\text { P. lilacinum. } \\
\text { Aspergillus niger }\end{array}$ & $\begin{array}{l}\text { C.M.I. 27830 } \\
\text { Chemistry Department, } \\
\text { University of Birmingham }\end{array}$ & $\begin{array}{l}\text { None } \\
\text { None }\end{array}$ & $\begin{array}{l}\text { None } \\
\text { None }\end{array}$ \\
\hline A. amstelodami & C.M.I. 17455 & + & + \\
\hline $\begin{array}{l}\text { Trichoderma } \\
\text { viride }\end{array}$ & C.M.I. 45553 & ++ & + \\
\hline T. viride & $\begin{array}{l}\text { I.C.I. Ltd., Akers Re- } \\
\text { search Laboratories } \\
\text { ARL } 211\end{array}$ & ++ & None \\
\hline $\begin{array}{l}\text { Fusarium monili- } \\
\text { forme }\end{array}$ & C.M.I. 45499 & ++ & None \\
\hline F. roseum & $\begin{array}{l}\text { Philadelphia Q.M. Depot, } \\
\text { U.S.A. Q.M. 388 }\end{array}$ & ++ & ++ \\
\hline Irpex lacteus & $\begin{array}{l}\text { Institute of Fermentation, } \\
\text { Osaka, Japan. Fr.no.5367 }\end{array}$ & + & + \\
\hline $\begin{array}{l}\text { Myrothecium } \\
\text { verrucaria }\end{array}$ & C.M.I. 44743 & + & + \\
\hline
\end{tabular}

+ , Indicates reducing sugar produced; ++ , indicates strong production of reducing sugar; C.M.I., Commonwealth Mycological Institute, Kew.

Partial separation of enzymes. After filtration through nylon cloth and removal of organism (Sharples Supercentrifuge), the medium was concentrated in a cyclone evaporator at $30^{\circ}$, and finally freeze-dried to give a red powder (33.5 g.). The powder (30.0 g.) was dissolved in water $(300 \mathrm{ml}$.) and dialysed against running tap water for $72 \mathrm{hr}$. over an acetylated cellulose membrane (Dr D. R. Whitaker, personal communication). After a trial fractionation of half of the dialysed solution, the remainder was freeze-dried; a solution of this material (14 g. in $285 \mathrm{ml}$. water) was fractionated by precipitation with freshly distilled ethanol at $0^{\circ}$, according to the protocol given in Table 2; all precipitates were allowed to stand at $0^{\circ}$ for $18 \mathrm{hr}$. before removal by centrifugation and freeze-drying. Precipitate $\mathrm{C}$ was then submitted to further fractionation. The activity of the fractions was assayed qualitatively by incubation with 
occasional agitation at $30^{\circ}$ for $48 \mathrm{hr}$. of an aqueous solution of the fraction with (a) finely divided xylan, and (b) cellulose (Whatman Filter Paper Powder, Standard Grade); samples were analysed by paper chromatography.

Properties of fraction $G$. The enzymic activity of fraction $G$ was determined by incubation at $30^{\circ}$ of fraction $G(1 \mathrm{mg}$.) with finely powdered xylan $(100 \mathrm{mg}$.) usually in phosphate buffer (total phosphate concentration $0.099 \mathrm{M}$ ) under the conditions recorded below. The insoluble matter was finally removed by centrifugation, and the reducing sugars determined in the supernatant liquid by hypoiodite oxidation (Martin, Smith, Whistler \& Harris, 1941).

Table 2. Fractionation of culture medium

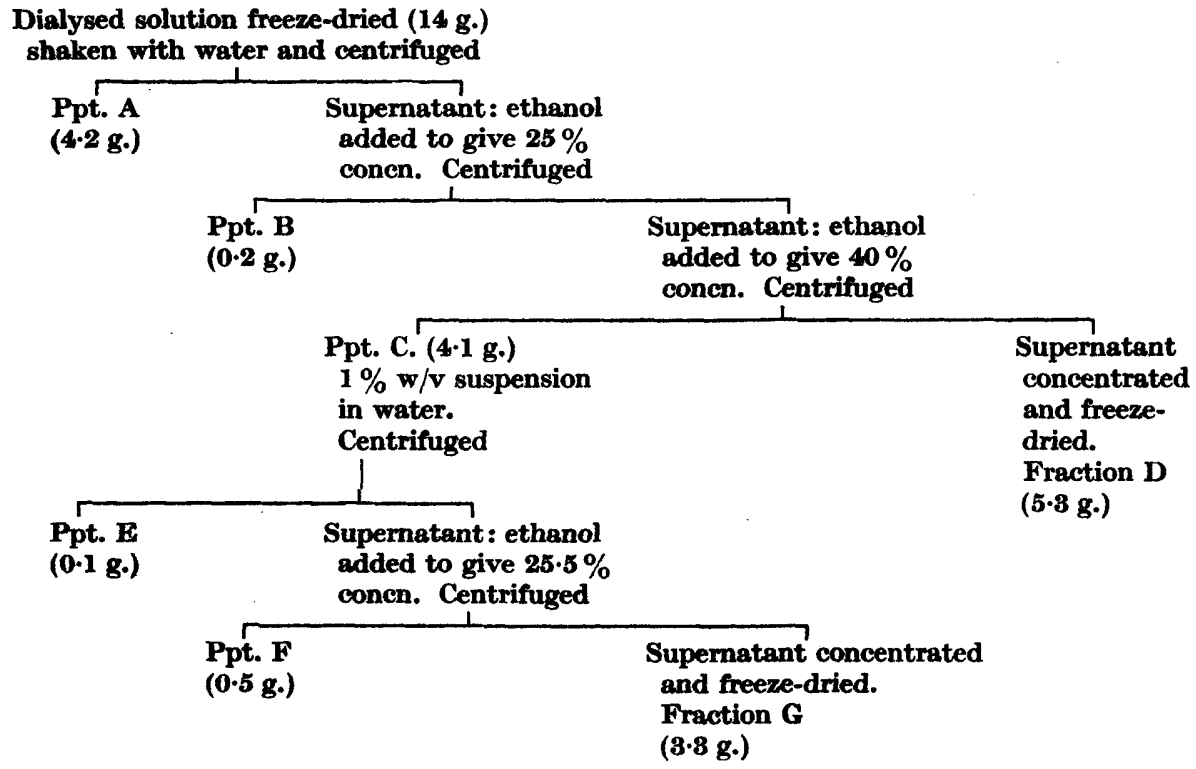

(All ethanol additions by volume)

\section{RESULTS \\ Enzyme activity of fractions}

The products of hydrolysis catalysed by the various precipitates and fractions are shown in Table 3 . It will be seen that precipitate $B$ and fraction $G$ are devoid of cellulase activity. The small quantity of precipitate $B(0.2 \mathrm{~g}$.) prevented further purification.

\section{Properties of the xylanases of Fraction $G$}

The results of the action of Fraction $G$ on xylan and other carbohydrates are given below :

(a) Rate of hydrolysis. The effect of time of incubation at $30^{\circ}$ on reducing sugar production by a constant weight of fraction $\mathrm{G}$ at $\mathrm{pH} 6.3$ in water is 
shown in Fig. 1. It can be shown that during the first $48 \mathrm{hr}$. the relationship between time and $\log _{e}(c / c-x)$ is linear $(c=$ initial xylan concentration, $x=$ reducing sugar produced expressed as anhydroxylose units); the rate constant for this reaction is $k=7 \cdot 3 \times 10^{-7}$ sec. ${ }^{-1}$.

(b) Optimum $\mathrm{pH}$ value. The effect of $\mathrm{pH}$ value on xylanase activity in phosphate buffer $(0.099 \mathrm{M})$ is shown in Fig. 2.

Table 3. Enzymic activities of fractions

Fraction
Ppt. A (largely
insoluble)
B
C

Fraction D

Ppt. E

$\mathbf{F}$

Fraction G

\section{Action on}

cellulose

Glucose

None

Glucose + cellobiose

Glucose +

trace of

cellobiose

Glucose + cellobiose

None

None

\section{Action on xylan}

Xylose, arabinose, glucose (trace only), and xylo-oligosaccharides

Traces of above compounds only

None

Traces of xylose

Xylose, arabinose, glucose (trace), and xylo-oligosaccharides

(c) Effect of added protein. Albumin (fraction V, Armour Laboratories) had no stimulatory effect on xylanase activity when added at concentrations of 9-455 $\mu \mathrm{g} . / \mathrm{ml}$. at $\mathrm{pH} 6 \cdot 3$.

(d) Effect of organic mercury compound. Xylanase activity of fraction $\mathbf{G}$ was not inhibited by $p$-chloromercuribenzoic acid (Na salt; L. Light and Co. Ltd.) at $\mathrm{pH} 6.3$ and concentrations of $0.0009 \mathrm{M}-0.005 \mathrm{M}$.

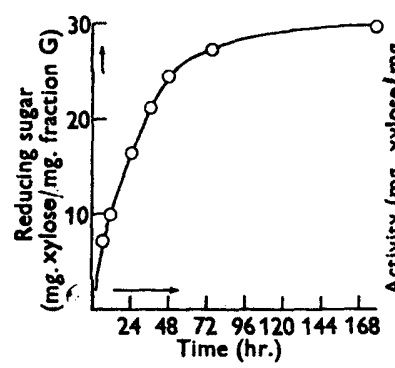

Fig. 1

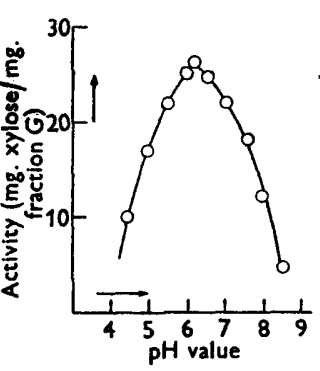

Fig. 2

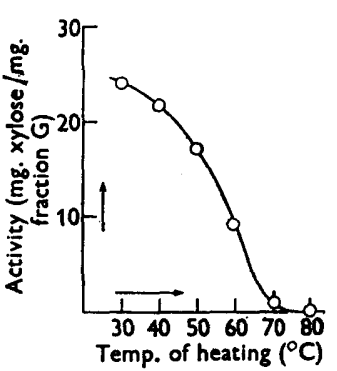

Fig. 8

Fig. 1. Xylanase activity of fraction G.

Fig. 2. Effect of $\mathbf{p H}$ value on activity.

Fig. 3. Thermal stability of xylanase.

(e) Thermal stability of xylanase. Fraction $\mathbf{G}$ was dissolved in water, maintained at different temperatures for 5 min., after which the xylanuse activity at $\mathrm{pH} 6.3$ and $30^{\circ}$ for $48 \mathrm{hr}$. was determined; the enzyme lost its activity on increasing the temperature of heating, as shown in Fig. 3. 
(f) Action on cellulose. Fraction G (2 mg.), dissolved in water (5 ml., pH 5.8), was without action on filter-paper, powder, cotton, rayon or on cellulose swollen in phosphoric acid for $1 \mathrm{hr}$. at $2^{\circ}$ (prepared according to the method of Walseth (1952)) (100 mg. each substrate) when incubated at $30^{\circ}$ for $24 \mathrm{hr}$.

(g) Action on $\alpha$-cellulose containing xylose (1\%). This $\alpha$-cellulose was prepared from beech holocellulose by successive alkali extractions as described by Corbett \& Ewart (1959); xylose, a trace of glucose and xylo-oligosaccharides were detected by paper chromatography in the incubation mixture containing the substrate $(500 \mathrm{mg}$.) and fraction $\mathrm{G}(5 \mathrm{mg}$.) in water $(10 \mathrm{ml}$.) incubated at $30^{\circ}$ for 24 and $48 \mathrm{hr}$. No xylose-glucose disaccharides could be detected.

(h) Action on other carbohydrates. An aqueous solution (5 ml., $\mathrm{pH} 5 \cdot 8)$ of fraction G (2 mg.) was incubated for 24 and $48 \mathrm{hr}$. at $30^{\circ}$ with suspensions or solutions of various carbohydrates (50 mg. in $5 \mathrm{ml}$.); the solutions were then analysed by paper chromatography; the results are shown in Table 4.

(i) Nitrogen content of fraction $G$. This was $2 \cdot 3 \%$, corresponding to a protein content of c. $14 \%$.

Table 4. Enzymic activities of fraction $G$

\begin{tabular}{|c|c|}
\hline Substrate & Reducing sugars produced \\
\hline $\begin{array}{l}\text { Xylose } \\
\text { Xylobiose } \\
\text { Xylotriose }\end{array}$ & $\begin{array}{l}\text { Xylose + trace xylo-oligosaccharides } \\
\text { Xylose + xylo-oligosaccharides } \\
\text { Xylose + xylobiose + xylo-oligosac- } \\
\text { charides }\end{array}$ \\
\hline Cellobiose & $\begin{array}{l}\text { Glucose + cellobiose + cello-oligo- } \\
\text { saccharides }\end{array}$ \\
\hline Amylose & Glucose \\
\hline Chitin & None \\
\hline Araboxylan (rye flour) & Xylose + arabinose + oligosaccharides \\
\hline$\beta$-cellulose (spruce)* & None \\
\hline$\gamma$-cellulose (spruce)* & Xylose + hexoses + oligosaccharides \\
\hline
\end{tabular}

DISCUSSION

The enzymic hydrolysis of xylan has been investigated with very few pure enzymes. Two crystalline enzymes catalyse the hydrolysis of xylan to xylobiose and xylo-oligosaccharides, although another enzyme produces xylose from xylan probably by a transpentosylation reaction (Fukui \& Sato, 1957). However, Bishop (1956) was unable to show the presence of a transpentosylase in the cellulase of Myrothecium verrucaria; again, xylose did not appear in the hydrolysis products from xylan. The enzymes of Aspergillus foetidus have been separated into two components; both catalase the hydrolysis of cellulose and one component produces xylose and xylo-oligosaccharides from xylan (Whistler \& Masak, 1955). Recently, Preece \& MacDougall (1958) followed the pattern of pentosan degradation in a water soluble rye araboxylan. Four enzyme systems were detected in cereal extracts: $(a)$ arabinosidase, liberating free arabinose from araboxylan and from oligosaccharides; $(b)$ endoxylanase, degrading xylan chains, whether or not these contain arabinose side 
chains; (c) exoxylanase, producing xylobiose from araboxylan and from oligosaccharides after some arabinose had been removed; $(d)$ xylobiase, liberating free xylose from xylobiose, and perhaps, from xylotriose also. These workers considered that transpentosylation was unlikely as the enzymic attack on xylobiose gave no evidence of products other than those expected from direct hydrolysis. The fraction $G$, reported here, has transpentosylase activity and this complicates the interpretation of the mechanism of the hydrolysis of pentosans. In addition, it is possible that fraction $\mathbf{G}$ contains the four enzyme systems detailed above. Duncan, Manners \& Ross (1956) reported the hydrolysis of esparto grass xylan, catalysed by enzymes from Rhodymenia palmata, to give rise to xylose and xylo-oligosaccharides; this pattern is similar to that resulting from the experiments with fraction $G$. Another enzyme system similar in some respects to fraction $G$ was produced by Sørensen (1952) from the fungus Chaetomium globosum. Both these systems catalyse the random scission of the polyxyloside chain; however, the xylanase of Fraction $\mathbf{G}$ is less heat stable than Sørensen's enzyme.

Sørensen claimed that his xylanase was 'adaptive' (inducible), but this is difficult to reconcile with his results from the growth of Chaetomium globosum on mannan, cellodextrins, and soluble starch in which xylanase was produced to a small extent. It will be noted that the enzymes produced by Fusarium roseum grown on xylan contained both xylanase and cellulase; the fungus used had been maintained in culture for 3 years in the complete absence of cellulose. Only one sample of cellulase (Myers \& Northcote, 1959) has been reported recently which does not catalyse the hydrolysis of xylan. If the work of Monod, Cohen-Bazire \& Cohn (1951) is regarded as supplying a definition of inducible character, then the cellulase of Fusarium roseum should be regarded as constitutive, in line with the bacterial cellulases (Hammerstrom, Claus, Coghlan \& McBee, 1955).

It was not expected that albumin would stimulate xylanase activity in such a crude enzyme preparation which contains, in all some $14 \%$ protein. It has been shown that Myrothecium verrucaria ((Basu \& Whitaker, 1953) and Poria vaillantii (Sison, Schubert \& Nord, 1958) cellulases have sulphydryl groups associated with their active centres; the xylanase of fraction $\mathbf{G}$ is not inhibited by $p$-chloromercuribenzoic acid, and this probable absence of sulphydryl groups may serve as a diagnostic test if it can be proved that all cellulases contain such groups suitably placed.

We wish to thank Professor M. Stacey, F.R.S., Drs S. A. Barker and A. Sharples for their constant encouragement and advice. Drs G. O. Aspinall and W. M. Corbett are thanked for samples of various carbohydrates, and Miss B. J. Parkinson and Miss D. L. Peat for considerable experimental assistance. This work forms part of the programme of fundamental research undertaken by the council of the British Rayon Research Association; it was begun in the laboratories of the Department of Chemistry, University of Birmingham. 


\section{REFERENCES}

BasU, S. N. \& WhItaker, D. R. (1958). Inhibition and stimulation of the cellulase of Myrothecium verrucaria. Arch. Biochem. Biophys. 42, 12.

Bishop, C. T. (1956). Structure of a trisaccharide from wheat straw xylan. J. Amer. chem. Soc. 78, 2840.

Bose, S. R. \& Sarkar, S. N. (1937). Enzymes of some wood-rotting polypores. Proc. roy. Soc. B, 123, 193.

Chanda, S. K., Hirst, E. L., Jones, J. K. N. \& Percival, E. G. V. (1950). The constitution of xylan from esparto grass (Stipa tenacissima L.) J. chem. Soc. p. 1289.

Conbetr, W. M. \& Ewart, J. A. D. (1959). Separation of xylan from beech holocellulose. Svensk. Papperstidning, 62, 277.

Duncan, W. A. M., Manners, D. J. \& Ross, A. G. (1956). Enzyme systems in marine algae. Biochem. J. 63, 44.

Fuku,, S. \& Sato, M. (1957). Xylanase system of Aspergillus batatae. Bull. agric. chem. Soc. Japan, $21,392$.

hammerstrom, R. A., Claus, K. D., Coghlan, J. W. \& McBee, R. H. (1955). Constitutive nature of bacterial cellulases. Arch. Biochem. Biophys. 56, 123.

Martin, A. R., Smith, L., Whistler, R. L. \& Harris, M. (1941). Estimation of aldehyde groups in hydrocellulose from cotton. J. Res. nat. Bur. Stand. 27, 449.

Monod, J., Cohen-Bazire, G. \& Cohn, M. (1951). Sur la biosynthèse de la $\beta$-galactosidase (lactase) chez Escherichia coli. La specificité de l'induction. Biochim. biophys. Acta, 7, 585.

Myers, F. L. \& Northcote, D. E. (1959). Partial purification and some properties of a cellulase from Helix pomatia. Biochem. J. 71, 749.

Preece, I. A. \& MacDovgalx, M. (1958). Enzymic degradation of cereal hemicelluloses. Part II. Pattern of pentosan degradation. J. Inst. Brew. 64, 489.

Sison, B. C., Schubert, W. J. \& Nord, F. F. (1958). On the mechanism of enzyme action. LXV. A cellulolytic enzyme from the mold Poria vaillantii. Arch. Biochem. Biophys. 75, 260.

Sørensen, H. (1952). On the specificity and products of action of xylanase from Chaetomium globosum Kunze. Physiol. Plant. 5, 183.

Trevelyan, W. E., Proctor, D. P. \& Harrison, J. S. (1950). Detection of sugars on paper chromatograms. Nature, Lond. 166, 444.

WALSETH, C. S. (1952). Occurrence of cellulases in enzyme preparations from microorganisms. Tech. Pap. Pulp. Pap. Ind. N.Y. 35, T228.

Whistuer, R. L. \& Masak, E. (1955). Enzymatic hydrolysis of xylan. J. Amer. chem. Soc. 77, 1241. 